У, $\triangle \mathrm{K}[1: 316]: 323(470+571)$

ББК $60.027+66.3$ (2Poc)

DOI 10.22394/1682-2358-2019-2-48-56

O.V. Vdovichenko, postgraduate student of the Political Science Department, Povolzhsky Institute of Management named after P.A. Stolypin, Branch of the Russian Presidential Academy of National Economy and Public Administration

\section{CIVIL SOCIETY AND POLITICAL PROCESS IN THE REPUBLIC OF CRIMEA}

The problems of formation of civil society and development of the political process in the Republic of Crimea within the Russian Federation are considered. The peculiarities of interaction between the structures of state power and civil society are revealed, its effective forms are determined. The organizing and coordinating role of the Public Chamber of the Republic in the system of relations between public authorities and public organizations is emphasized.

Key words and word-combinations: civil society, regional political process, Public Chamber, interaction.
О.В. Вдовиченко, аспирант кафедрог политических наук Поволжского института управления имени П.А. Стольтина - филиала Российской академии народного хозяйства и государственной службь при Президенте РФ (email: kafpolitology@piuis.ru)

\section{ГРАЖААНСКОЕ ОБЩЕСТВО И ПОАИТИЧЕСКИЙ ПРОЦЕСС В РЕСПУБАИКЕ КРЫМ}

Аннотацчия. Рассматриваются проблемы становления гражданского общества и развития политического процесса в Республике Крым в составе Российской Федерации. Раскрываются особенности взаимодействия структур государственной власти и гражданского общества, определяются его эффективные формы. Подчеркивается организующая и координирующая роль Общественной палаты Республики в системе отношений органов власти и общественных организаций.

Ключевые слова и словосочетания: гражданское общество, региональный политический процесс, Общественная палата, взаимодействие.

B середине марта 2019 г. российская общественность широко отметила пятилетний юбилей возвращения Крыма в состав России. Обеспеченный героизмом активных патриотов и массовой подлержкой подавцяющего большинства крымчан факт законного выхода Крыма из состава Украины и вхождение в состав Российской Федерации 
явцяется историческим событием огромного политического значения. С позиџии крымского общества это свидетельствует и о гражданской активности, политической зрелости населения полуострова, в сложной, непреАсказуемой обстановке проявившего солидарность и совершившего ответственный политический шаг.

Массовое осознание крымчанами своих региональных интересов обусцовлено мощными исторически традиџионными связями с Россией, ощушением себя частью российского народа, единством русской национальной культуры и языка, Ауховными корнями и потребностями. Все это спцотило граждан разных национальностей и конфессий в единое сообщество, тяготеющее к России. Аанный аспект интересен в особой степени еще и потому, что накануне, по мнению крымских исследователей, гражданское общество на полуострове еше не было сформировано, а политический проџесс оџенивался как неструктурированный, наполненный разногласиями, неспособный выразить и реализовать интересы гражданского общества [1].

О развитии гражданского обшества Крыма в усмовиях украинской субъектности написано немного, но некоторые особенности данного процесса исследовались достаточно основательно. Так, статья И.В. Островской посвящена обшественным организациям караимов и крымчаков, а в статье А.Ю. Полунова исследуется политическое участие русских общественных организаций Крыма [2; 3]. Авторы в обоих случаях показывают эффективность деятельности общественных структур, но в то же время подчеркивают существенные разцичия в их интересах.

О прежней расколотости крымского обшества свидетельствуют многие Аанные, полученные через опросы населения и экспертные заключения, проводившиеся в течение всего периода нахождения Крыма в составе независимой Украины [4]. Немалую сложность представлямо национально-конфессиональное многообразие Крыма, разделившее население на множество групп, имевших особые интересы [5]. Конфликтогенными факторами также являлись напряженные отношения между Россией и Украиной, незавершенность реабилитации ранее репрессированных народов, последствия сложных миграционных перемещений населения в советский и досоветский периоды крымской истории, политическая активизация крымско-татарского населения вокруг идеи создания этнической автономии.

Несмотря на это, крымчан объединимо стремление вернуться в состав России, стать россиянами. Такая политическая позиция оказалась преобладающей, оттеснив на периферию общественного сознания проблемы, разъединявшие народ, и оформив единство воли огромного количества Аюдей. По сути, состоялся массовый порыв восставшего народа. Российская поддержка обеспечила ему успех. Но за этим мошным эмоциональным всплеском последовало неизбежное возвращение к обыденной жизни, где прежние факторы, затруднявшие политическое единство народа, тормозившие процесс формирования эффективного гражданского общества, проявились вновь негативно и масштабно. Гражданское обшество Республики Крым должно было вступить в новый период развития. 
Базовым фактором переструктурирования совокупности общественных объединений Крыма явмялась политико-правовая система Российской Федераџии, принџипиально отличающаяся от украинской. Всем существовавшим организаџиям следовало перерегистрироваться в соответствии с российским законодательством и ориентироваться на российские принџипы, џенности и общественно-политические отношения. Естественно, что некоторые существовавшие в «украинское время» организаџии прекратили свою деятельность, а некоторые создавались уже на иной политической основе. Особенно сложными и запутанными оказались проџессы в сфере конфессиональных отношений.

Регистрацию общественных организаций осуществмяло Управление Министерства юстиции Российской Федераџии по Республике Крым на основании Федерального закона от 12 января 1996 г. № 7-Ф3 «О некоммерческих организациях». Кроме того, уставные документы общественных организаций должны были соответствовать федеральному законодательству и законодательным актам Республики Крым. На этот массив законодательства накладывалась политическая мотивация общественных организаџий, что определенным образом воздействовало на процедуры рассмотрения регистрируемых документов. Совокупность отмеченных обстоятельств неизбежно растягивала сроки регистрации общественных организаций.

Несмотря на это, к 1 января 2015 г. в Республике Крым насчитывалось свыше 300 вновь зарегистрированных общественных организаций, 30 благотворительных фондов, 15 политических партий. К середине февраля 2015 г. были зарегистрированы уже 482 некоммерческие организации и 21 политическая партия [6, с. 51]. В течение года процесс регистрации новых организаций нормализовался: к началу 2018 г. в Республике Крым на официальном уровне действовали 3112 некоммерческих организаџий, 72 казенных общества, 99 национально-культурных автономий, 1149 обшественных организаций $[7$, c. 13]. Все они в разной степени консолидируют интересы респубциканского населения и представцяют их переА властями местного, регионального и федерального уровней.

Институтом, объединяющим и координирующим деятельность большинства этих организаций, явмяется Общественная палата Республики Крым, чье место и роль в системе гражданского общества Республики подчеркивается тем, что ее созданию посвящен первый принятый Государственным Советом Республики Крым Закон Республики Крым от 15 мая 2014 г. «Об Общественной палате Республики Крым» [8] . Тем самым государственная власть демонстрироваца ответственное отношение к мнению обшественности, к роли гражданского общества в организации жизни региона, к взаимодействию структур власти с общественными организаџиями, преАставцяющими гражАан региона.

За пять мет существования Общественная палата Республики Крым сформировалась в качестве важнейшего института регионального сообщества, осушествмяющего качественную экспертизу законопроектов, обеспечивающего Аиалог между населением и властью в важных сферах региональной 
политики: межнациональных и конфессиональных отношений, экологии, зАравоохранения, образования, культуры, антикоррупџионных мероприятий. Ежегодно руководство общественной палаты готовит и обнародует объемные докмады «О состоянии гражданского обшества в Республике Крым», дающие представление о развитии гражданского общества в регионе, о настроениях и интересах населения, о деятельности самой палаты, о ее взаимодействии с Аругими субъектами региональной политики. Материалы ежегодных докмаАов Общественной палаты представляют собой важный источник анализа обшественно-политического развития Республики Крым за данный период исторического развития, в частности, Аают возможность глубже осознать совокупность трудностей интеграџии Крыма в российское государственное пространство.

Политический проџесс в регионе развивался сложно. В период украинской принадмежности Крыма власти проводили политику украинизации Республики через образовательные учреждения, навязывая национацистическую трактовку исторического прошиого российских народов, через каАровую и пропагандистскую политику, через захват производственных объектов, земель, цечебно-оздоровительных местностей украинским бизнесом и чиновничеством. Особой политической минией Киева в Крыму явцялось насаждение антироссийских настроений, при этом активно использовался крымско-татарский фактор с џелью разжигания напряженности и конфмиктов на почве соџиальной и психологической неустроенности значительной части крымско-татарского населения. Создавалась обстановка соџиально-политической неустойчивости, навязывалось негативное отношение к России.

Несмотря на давление украинских властей и националистических организаџий, в Крыму доминировали пророссийские политические партии и общественные движения, среди которых наиболее активной и последовательной была партия «Русское ЕАинство», возглавляемая С.В. Аксеновым. Большинство населения подАерживало их деятельность по сохранению российской идентичности, развитию культурных и торгово-экономических связей с Россией. Этот общественный настрой крымчан проявился на референдуме 2014 г., когда почти 97\% голосовавших высказались за вхождение Крыма в состав России [6, с. 8].

С вхождением Республики Крым в состав Российской Федерации усилияся Аинамизм политического проџесса, характеризующийся существенными изменениями в политической структуре региона. В течение короткого времени (весна - мето 2014 г.) были приняты Конституция Республики Крым, ряА важнейших законов (о реабилитации репрессированных народов Крыма, об Общественной палате и Ар.), целевая программа «Соџиально-экономическое развитие республики Крым и г. Севастополя на период до 2020 года» и т.А., что послужимо созданию новой политико-правовой базы государственного развития общественных отношений в Республике. Произошла переструктуризация партийного пространства по аналогии с партийной системой России: в избирательной кампании на выборах в Государственный Совет Республики 
и местных органов власти, состоявшихся 14 сентября 2014 г., участвовали десять партий. Из 75 избранных депутатов Госсовета семьдесят представмяли партию «ЕАиная Россия» и пять - $\Lambda$ ПР [9, с. 19]. СреАи депутатов местного уровня большинство также являлись представителями «ЕАиной России». Высокий уровень доверия крымчан правящей партии свидетельствовал о большом авторитете Президента РФ В.В. Путина среди крымского населения и о серьезных надеждах на существенное улучшение их жизни в составе российского государства.

ОАновременно с развитием политической системы Республики, усилением и укреплением в ней российских эмементов происходимо формирование регионального гражданского общества. Этот проџесс также отмичался определенными особенностями.

Во-первых, в начальный период перехода Крыма под российскую юрисАикцию в Республике не существовало местных общественных организаций, и крымчане участвовали в общественной деятельности через сотрудничество в обшероссийских общественных организаџиях. Аишь постепенно, с мета 2014 г., развернулся проџесс создания региональных некоммерческих организаций. Они вкмючались в общественную жизнь региона, перенимая опыт отделений всероссийских организаций, в том числе путем проведения совместных мероприятий и общественно-политических акщий. В первые годы сушествования активность большинства крымских некоммерческих организаций оставалась невысокой. По данным соџиологических исследований РАН, проведенных весной 2017 г., более 67\% зарегистрированных в Республике Крым некоммерческих организаџий фактически бездействовали [7, с. 11]. Причинами такого положения явмялись отсутствие практического опыта общественной деятельности, бюрократические ограничения общественной активности населения, недостаточная ориентированность в происходивших политических событиях, авантюрные наклонности отдельных организаторов-активистов, наличие пассивной, выжидательной позиции отАельных групп населения Республики. Аанные препятствия требовали преодоления, соответствующей реакщии республиканских и местных властей, позитивно настроенных активистов, патриотических объединений и отделений парламентских партий.

Во-вторых, ответственной проблемой с момента вхождения Республики Крым в состав Российской Федераџии остается характер восприятия крымчанами российского гражданства. Суть проблемы состоит в преимущественной самоидентификации крымчан по этническому, а не гражданскому принципу. Несмотря на то что абсолютное большинство жителей Республики, за исключением нескольких проџентов, в 2014-2015 гг. получили паспорта граждан России, при проводимых опросах более $50 \%$ отмечают принадмежность к какому- ибо этносу как важнейшую характеристику и мишь после этого определяют себя еще и гражданами Российской Федерации. Такой характер самоидентификаџии мюдей не следует оџенивать искмючительно позитивно или негативно. ОАнако в условиях сложной национальной структуры крымского сообщества это может свидетельствовать о сильной этни- 
ческой разобщенности крымского общества при слабом воздействии объединяющего фактора - общей принадлежности к российскому народу. При таком подходе этническая самоидентификаџия выступает преимущественно в качестве негативной характеристики.

В-третьих, преобцадание негативного контекста в информационном пространстве региона оказало сильное воздействие на крымское обшество. Отриґательное отношение распространялось на социальное положкение мюАей, межнациональные и религиозные отношения, качество управленческой деятельности на республиканском и муниципальном уровне, отношения с Украиной и т.А. Негативизм преподнесения различной информации, оџенивания происходивших событий, фактов исторического прошиого и современной политики широко культивировался оппозиџионными СМИ и нелегально Аействующими экстремистскими организаџиями, вещающими из-за рубежа средствами массовой информации Украины и некоторых стран НАТО. Цемь подобных действий - внушать мюдям недоверие к новым властям и проводимой ими политике, провоцировать конфликтность и агрессивность общественных отношений, мюбыми путями снижать позитивную активность населения Республики. Подчеркнем, что некоторое время власти относились к этому сектору медиа-пространства как к проявлению свободы слова и мнений, необходимых в демократическом обществе, не оџенивая его в качестве враждебной позиции политического противника и не предпринимая мер противодействия.

Наличие этих факторов осложняло процесс формирования гражданского общества в Республике Крым и, по нашему мнению, требовало особых отношений межАу общественными и властными структурами. На первый план Аолжно бымо выйти активное сотрудничество, оттесняющее на второе - третье места оппонирование и критику власти со стороны общества. Такова помитическая особенность периода вхождения Крыма в Российскую Федераџию. ВАасти испытывали те же общественные обстоятельства, условия деятельности, что и организации, объединения граждан.

На этом основании взаимодействие власти и общества приобретало особую актуальность. Необходимость такого взаимодействия сознавалась обеими сторонами, но, судя по содержанию ежегодных отчетов Общественной палаты Республики Крым, с большей ответственностью к этому проџессу относились наиболее прогрессивные и патриотически активные общественные структуры. Такая оценка вытекает из анациза основных направлений происходившего взаимодействия: создания и обеспечения деятельности общественных советов при структурах государственной и мунищипальной власти; осуществления экспертизы законопроектов, материалов СМИ, соАержания деятельности религиозных и национальных организаций; выявмения и анализа проблем регионального развития, выработки решений или программ деятельности; проведения совместных общественно значимых мероприятий. Совместная деятельность управленческих и общественных структур, ее координация на разных этапах обеспечиваци более высокую 
эффективность реализации региональной политики по каждому из названных направлений.

Общественные советы при органах власти создавались с 2015 г. на основе федерального и регионального законодательства. Их принципиальная задача - связывать деятельность власти с интересами местных сообществ, осуществлять общественный контроль за властью. Наиболее активное участие в организащии советов, в обеспечении их работы принимала Общественная палата Республики Крым; она же оџенивала эффективность данной формы взаимодействия власти и общества, выделяла успешную практику, стремимась распространить ее среАи всех участников подобных отношений.

В середине 2016 г. Общественная палата провела мониторинг деятельности обшественных советов, в рамках которого выявились слабые места этого направления. Некоторые слабости проистекали из-за некачественного состава советов, неподготовленности их чиенов к исполнению возможенных обязанностей, пмохой коммуникаџии общественных советов с НКО, поверхностного содержания их предложений и рекомендаций. Но одновременно с этим обнаружились проблемы, возникшие по причине отсутствия намеченного партнерства во взаимоотношениях с органами власти. Нередко чиновники игнорировали иниџиативы и оџенки общественных советов, не обеспечивали необходимые условия для их работы, не предоставцяли чменам советов документы и информацию для экспертного анализа и составления обоснованных закмючений. Общественная палата разработала предложения по улучшению деятельности общественных советов, представила их в региональное правительство. Предложения были приняты, уровень ответственности органов исполнительной власти в отношениях с общественными советами постепенно повысияся, работа с ними приобрела системный характер.

Ответственной задачей для гражданского общества явмяется систематическая экспертиза деятельности органов государственной власти, в том числе Аеятельности законотворческой, организаџионной, информационной. Общественная палата во многом координирует эту работу, определяя проблемы, подбирая экспертов и создавая аналитические группы, оџенивая полученные экспертные заключения. В 2016 и 2017 гг. осуществлена экспертиза примерно двух десятков законопроектов, подготовленных в государственном Совете Республики Крым. К процедуре проведения экспертиз привлекались ученые Крымского федерального университета, журналисты, практикующие юристы и преАприниматели, преАставители наџионально-культурных автономий. Практически весь процесс республиканского законотворчества протекает при экспертном участии Общественной палаты, которая на ежегодных заседаниях заскушивает и утверждает отчеты об общественной экспертизе законопроектов.

Общественная экспертиза по другим сферам касается деятельности не только властей, но и иных субъектов, формирующих идейные и нравственно-психологические настроения цюдей. В частности, анализируются содержание и форма работы национальных обществ, религиозных общин,

54 Bulletin of the Volga Region Institute of Administration • 2019. Vol. 19. № 2 
информационных теле- и радиоканалов, печатных изданий. Постоянно проводится изучение общественного мнения, его результаты сообщаются в органы власти. Обычно экспертные закмючения общественников по этим сферам подАерживаются органами исполнительной власти.

Масштабная работа проводится общественными организациями по выявлению актуальных проблем развития в республике в целом и по районам и конкретным объектам в частности. Многие вопросы инициированы местными жителями и вынесены на общественное обсуждение правозащитными, экологическими, культурно-наџиональными, молодежными и другими организациями. Благодаря этому большой резонанс в крымском сообшестве в разные годы получали пробцемы патриотического воспитания молодежи, языковой политики, шефства наА памятниками и братскими могилами, преподавания истории Крыма в системе школьного и вузовского образования, государственной подАержки производителей сельскохозяйственной продукции, пострадавших по причине блокады водо- и энергоснабжения со стороны Украины, охраны ряда природных объектов и насеменных пунктов от ухудшения экологической обстановки в регионе и другие актуальные вопросы. По каждому из них проводились общественные слушания, дискуссии, научно-практические конференции, встречи с заинтересованными группами населения; формировались общественные интересы, предложения, требования, Аоводимые до соответствующих органов власти; вырабатывались совместные решения, реализация которых во многих случаях удовлетворяла интересам насемения.

Наиболее распространенной формой взаимодействия структур вмасти и гражданского общества явмяется проведение совместных мероприятий, посвященных актуальным аспектам региональной политики. С 2014 г. попумярны круглые столы по различным актуальным проблемам, организуемые обшественными структурами при активном участии преАставителей респубмиканской и муниџипальной вмасти. Тематика встреч разнообразна, но всегда связана с текущей повесткой региональной политики: разработка программ социально-экономического развития, организация и проведение избирательной кампании, развитие межнационамьных отношений, деятельность национально-культурных автономий, анализ экологической обстановки на территории региона. Различные змободневные вопросы обсуждаются в рамках конференций и обучающих семинаров. Большое внимание уделяется организаџии массовых мероприятий, связанных с культурными традиџиями разных наџиональностей, с историческими событиями в Крыму, с памятными Аатами, религиозными праздниками, охраной природных объектов. Многие мероприятия носят военно-патриотическую и просветительскую направяенность. Существенным результатом большинства проводимых мероприятий явмяется наглядная демонстрация эффективности совместных действий структур власти и гражАанского общества.

Современное общественно-политическое развитие Республики Крым в значительной степени обеспечивается взаимодействием властных и общественных структур. Оно расширяется, усиливается, охватывает весь спектр интере- 
сов обшества и власти. Повышается качество участия структур гражданского общества в региональном политическом проџессе, что положительно влияет на эффективность государственного и муниципального управления. Накоплен значительный практический опыт взаимодействия, необходимый Аля Респубмики Крым, переживаюшей сложный, но перспективный периоА модернизации в составе Российской Федерации.

\section{Библиографический список}

1. Бекиров С.Н., Бекирова Э.Ш. Особенности политического процесса в Крыму // Проблеми сучасної педагогічної освіти: збірник статей. Ялта, 2009. Вип. 23, ч. 2. С. 3-8.

2. Островская И.В. Взаимодействие общественных организаций караимов и крымчаков с органами власти Автономной Республики Крым // Вестник СЕВНТУ. Севастополь, 2012. № 136. C. $232-236$.

3. Полунов А.Ю. Общественные организации русского Крыма: политическая деятельность, стратегии взаимоотношений с властью // Государственное управление. Электоральный вестник МГУ имени М.В. Ломоносова. 2009. № 21. С. 24-28.

4. Никифоров А.P. Специфика крымского региона в политическом пространстве Украины // Регіональні проекції державної політики: збірник наукових праць / відп. ред.: О.Г. Старіш. Сімферополь, 2003. Т. 1. С. 28-41.

5. Сомов М.В. Межэтнические отношения в автономной республике Крым: результаты исследований // Таврийская студия. История. 2012. № 2. С. 44-53.

6. Межэтнические отношения и религиозная ситуация в Крымском федеральном округе. Экспертный доклад 2015 / под общ. ред. В.А. Тишкова. Москва; Симферополь, 2015.

7. О состоянии гражданского общества в Республике Крым в 2017 году: доклад Общественной палаты Республики Крым. Симферополь, 2018.

8. Об Общественной палате Республики Крым: Закон Республики Крым от 15 мая 2014 г. № 01-3PK. URL: https://www.garant.ru/hotlaw/crimea/545980/

9. О состоянии гражданского общества в Республике Крым в 2014 году: доклад Общественной палаты Республики Крым. Симферополь, 2015. С. 19. 